\title{
Kinetics of Oxidation of Triaryl Methane Dye, Brilliant Blue-R with Chlorine Dioxide
}

\author{
Srinivasu Nadupalli, Venkata D.B.C. Dasireddy, Neil A. Koorbanally and \\ Sreekantha B. Jonnalagadda* (iD $\$$ \\ School of Chemistry \& Physics, University of KwaZulu-Natal, Westville campus, Durban, 4000, South Africa.
}

Received 12 September 2018, revised 16 December 2018, accepted 16 December 2018

\begin{abstract}
The fast decolourization of multi-purpose dye, Brilliant blue $\left(\mathrm{BB}^{-}\right)$oxidized by chlorine dioxide was investigated using the stopped flow technique under varied $\mathrm{pH}$ conditions by monitoring its oxidation kinetics. The products were identified and reaction mechanism is described, which is confirmed by kinetic simulations. Under $\left[\mathrm{ClO}_{2}\right]_{0}>\left[\mathrm{OH}^{-}\right]_{0}>\left[\mathrm{BB}^{-}\right]_{0}$ conditions, the oxidation kinetics showed first-order dependence on $\mathrm{BB}^{-}$and chlorine dioxide. The overall second-order rate coefficient enhanced with increasing $\mathrm{pH}$, and values were $30.2 \pm 0.2 \mathrm{M}^{-1} \mathrm{~s}^{-1}, 42.5 \pm 0.8 \mathrm{M}^{-1} \mathrm{~s}^{-1}$ and $117.9 \pm 0.8 \mathrm{M}^{-1} \mathrm{~s}^{-1}$ at $\mathrm{pH}$ 7.0, 8.0 and 9.0, respectively. In the $\mathrm{pH}$ range 7.0 to 9.0 , the catalytic constant for $\left[\mathrm{OH}^{-}\right]$catalyzed reaction was $9.0 \times 10^{6} \mathrm{M}^{-2} \mathrm{~s}^{-1}$ with energy of activation of $50.06 \mathrm{~kJ} \mathrm{~mol}^{-1}$. Observed negative entropy of activation of $-658.73 \mathrm{~J} \mathrm{~K}^{-1} \mathrm{~mol}^{-1}$ suggests the formation a compact transient activated complex.
\end{abstract}

KEYWORDS

Dye, oxidative degradation, chlorine dioxide, tertiary treatment, stopped flow study, fast kinetics.

\section{Introduction}

Virtually every manmade material comprises either a dye or pigment. A wide range of modified natural and synthetic dyes are used to colour fabrics, leather, paper, ink, lacquers, varnishes, plastics, cosmetics, and many other odd items. ${ }^{1}$ Robinson et al. in their review, reported that over ten thousand types of dyes or pigments are in use for various purposes. ${ }^{2}$ Approximately ten million tons of various dyes and pigments are produced and used per annum. ${ }^{3}$ Huge quantities of these dyes and pigments entering the wastewaters pose severe health risks and contribute to environmental disasters. ${ }^{2}$ Approximately two-thirds of the dyes consumed are used by the textile industry to dye fabrics, about one-sixth are used for colouring paper; and the rest are used primarily in the production of organic pigments and in the dyeing of leather and plastics. ${ }^{4}$ Due their refractory and toxic nature, many dyes are not easily degradable, hence remain in water systems for longer periods. ${ }^{5}$

Reportedly in textile industry, among various synthetic dyes, triarylmethane type dyes are more popularly used due their cost effectiveness, which contribute to about $30-40 \%$ of the total dyes and pigments used. ${ }^{6}$ These dyes are mainly derivatives of colourless triphenylmethane and diphenylnaphthylmethane and are characterized by a central carbon atom joined to three aromatic rings. In addition to textile dyeing, these chemicals have wide range of applications including as colouring agents in foodstuffs, cosmetics, paper, leather, varnish, etc., to mention a few. ${ }^{7,8}$ Some triaryl dyes are used as for staining biological and bacteriological specimens and as targetable photo sensitizers. ${ }^{7}$ Many triarylmethane dyes are eco-toxic. Crystal violet $(\mathrm{CV})$ is used to dye paper and for printing, in ball pens and inkjet printers, but it is reported to be toxic and may cause human bladder cancer, renal, hepatic and lung tumours. The intake of Malachite green (MG), a commonly used triarylmethane dye, could cause carcinogenic symptoms and lung adenomas. Photo-catalyzed

* To whom correspondence should be addressed.

E-mail: jonnalagaddas@ukzn.ac.za degradation of $\mathrm{MG}$ and $\mathrm{CV}$ in water treatment by using $\mathrm{BaO}_{3} \mathrm{TiO} . \mathrm{SrO}_{3} \mathrm{TiO}$ as catalyst has been reported. ${ }^{9}$ Gentian violet $(\mathrm{GV})$, another normally used triaryl-methane dye with antiseptic properties, has been used in medicine for over 100 years, is a component of surgical marking pens. GV causes cell and tissue death and potentially impairs cell migration. ${ }^{10}$ Another frequently used dye of this class, Light green SF (LG) reportedly could interfere with metabolic systems. ${ }^{11}$ LG causes irritation, when inhaled or consumed, and on contact it could also permeate the skin and accumulate in the body. ${ }^{12}$ LG and its metabolites reportedly could prompt carcinogenicity in organisms ${ }^{13}$ and produce sarcomas. A longer exposure to LG is reported to cause a blood disorder namely methemoglobinaemia. ${ }^{14,15}$ Taking into consideration the detrimental effects and potential toxicity of these dyes, it is of paramount importance to understand their degradation mechanisms and to remove these dyes from wastewaters and aquatic bodies.

Forgacs et al. ${ }^{16}$ reviewed the methods of removal of synthetic dyes from wastewater. Over the years, various techniques including the use of absorbents, ${ }^{14-17}$ oxidative degradation, ${ }^{18}$ photo-degradation, ${ }^{19}$ electrolysis ${ }^{20}$ electrocoagulation, ${ }^{21}$ degradation using fungi, ${ }^{22}$ enzymes, ${ }^{23}$ microbes ${ }^{24}$ and biochemical degradation ${ }^{25}$, have been reported for the removal of dyes and toxic organics from water systems, to mention a few. Due to the toxic nature of the effluents, many times biological degradation methods either fail or have limited success. Due to non-biodegradability associated with their toxicity, conventional biological treatment methods will be futile in degradation of dye materials and removal of colour from wastewaters. Hence, chemical approachs has to be adopted. ${ }^{26}$ Earlier, we reported the oxidative decolourization of MG with peroxydisulfate, ${ }^{27}$ triaryl methane dyes - Thymol blue and Aniline blue by acidic bromate in aqueous solutions. ${ }^{28,29}$ We have also reported the scope of ozone and hypochlorite as oxidants in degradation of Amaranth, an azo dye..$^{30,31}$ The extent of degradation of the dyes in these studies varied with nature of oxidant and oxida- 
tion duration, offering partial oxidation to complete mineralization.

In the recent past, we investigated the potential of chlorine dioxide, in decolourization of Amaranth under varied $\mathrm{pH}$ conditions by kinetic approach and elucidating the reaction mechanism and establishing the role of hydroxide ion ${ }^{32}$ and its potential in microbial disinfection. ${ }^{33}$ Based on the earlier successes, emphasis of the current study is the oxidative decolourization Brilliant blue- $R$, a triaryl methane anionic dye $\left(\mathrm{BB}^{-}\right)$, under aqueous conditions using chlorine dioxide as oxidant. Brilliant blue- $R$ is also known as Coomassie brilliant blue and Brilliant indocyanine $6 \mathrm{~B}$. Firstly, $\mathrm{BB}^{-}$was generated as a textile dye for dyeing wool, silk, nylon etc., but it is also extensively used in paint and leather industries. ${ }^{34}$ It is water-soluble dye and it readily dissociates into $\mathrm{BB}^{-}$and $\mathrm{Na}^{+}$and reveals significants peaks at 285 and $555 \mathrm{~nm}\left(\lambda_{555 \mathrm{~nm}}=4.3 \times 10^{4} \mathrm{M}^{-1} \mathrm{~cm}^{-1}\right) \cdot \mathrm{pH}$ variation has no effect on its spectrum. ${ }^{35}$ Recently, we reported the mechanism of decolourization of Brilliant blue by hypochlorite/hypochlorous acid under varied $\mathrm{pH}$ conditions. ${ }^{36}$

Although, chlorination is the most cost effective means in water treatment, its efficiency depends on the method of the process and water $\mathrm{pH} .{ }^{37}$ The main limitation of chlorination in treating water polluted with organics is its potential to form chlorinated hydrocarbons and trichloromethanes, which more hazardous than original, as those are carcinogenic. ${ }^{38,39}$ Among different chemicals used as chlorine alternatives in water treatment; chlorine dioxide has attracted sizeable attention, due its distinctly different properties, although it contains chlorine. ${ }^{40}$ Chlorine dioxide is recognized as a pre-oxidant and primary disinfectant during treatment of drinking water to avoid the formation of trichalomethane. ${ }^{41,42}$ Chlorine dioxide is also used for colour removal and odour control of waters in addition to oxidative removal of iron and manganese. Reportedly, over 800 water works practice chlorine dioxide usage for drinking water treatment. ${ }^{43}$ This communication emphasies on the kinetics of fast decolourization of Brillaint blue, its reaction mechanism, and identification of reaction products, immediately after its decolourization, i.e. not waiting for a long reaction time.

\section{Experimental}

Brilliant blue-R (Aldrich, USA $95 \%$ purity) was used with no further purification. Sodium hydroxide (BDH), sodium chlorite (BDH), $98 \%$ sulfuric acid (BDH) Analar grades were used as supplied. The stock solution was further diluted requisite to the need of experiments. The stock solution of aqueous $\mathrm{ClO}_{2}$ was prepared by acidifying sodium chlorite and stored in the dark. $\mathrm{ClO}_{2}$ solutions were standardized prior to use. ${ }^{31}$

\section{Results and Discussion}

\subsection{Kinetic Runs}

Kinetic experiments were conducted at $25 \pm 0.1^{\circ} \mathrm{C}$ with surplus concentrations of the other reagents relative to the substrate dye, which was monitored. A HI-TECH micro-volume double mixing stopped-flow apparatus was used to monitor the reactions. The data collected at selected fixed wavelength was analyzed using the KinetAsyst ${ }^{\mathrm{TM}} 3.10$ software. The KinetAsyst $^{\mathrm{TM}}$ software facilitates the estimation of the rate constants by matching of absorbance versus time data with different rate equations.

\subsection{Reaction Orders for $\mathrm{ClO}_{2}$ and $\mathrm{BB}^{-}$}

The rates of reaction employing varied surplus initial concentrations of oxidant, at $\mathrm{pH}$ (9.0) and fixed ionic strength, monitoring the depletion of dye at low concentrations were carried out to determine the reaction order wrt the oxidant. All the kinetic runs were conducted at $25( \pm 0.1){ }^{\circ} \mathrm{C}$ unless otherwise specified. Figure 1 illustrates the dye depletion as function of time at $\mathrm{pH} 9$, for concentrations $\left[\mathrm{ClO}_{2}\right]_{0}=1.5 \times 10^{-2} \mathrm{M}$ and $[$ dye $] 0=2.0 \times 10^{-5} \mathrm{M}$. An observation of the curves indicates that the dye was consumed very quickly in $<2 \mathrm{~s}$. Using kinetic fit software, the kinetic data were analyzed and found to fit well with the first-order equation suggesting that reaction follows first-order kinetics for the chosen reaction conditions. The $\mathrm{k}^{\prime}$ (pseudo first-order rate constants) values were estimated at fixed ionic strength with varied $\left[\mathrm{ClO}_{2}\right]_{0}$ conditions. The slope of the log-log plot of $\left[\mathrm{ClO}_{2}\right]$ against $\mathrm{k}^{\prime}$ was 1.02 (corr. coeff. 0.99), positively designate the first-order rate dependance on the oxidant, $\mathrm{ClO}_{2}$ (Table 1).

Table 1 Pseudo first-order rate constants for the reaction between Brilliant blue and chlorine dioxide at constant ionic strength .

Reaaction conditions: $\left[\mathrm{ClO}_{2}\right]_{0}=2.5 \times 10^{-3}$ to $3.5 \times 10^{-3} \mathrm{M}$ with $\left[\mathrm{BB}^{-}\right]_{0}=2.0 \times$ $10^{-5} \mathrm{M}, \mathrm{pH}=9.0$ and ionic strength, $\mathrm{I}=0.128 \mathrm{M}$.

\begin{tabular}{cc}
\hline$\left[\mathrm{ClO}_{2}\right]_{0} / 10^{-2 \mathrm{M}}$ & $\mathrm{k}^{\prime} / \mathrm{s}^{-1, *}$ \\
\hline 2.52 & 2.98 \\
2.78 & 3.24 \\
3.03 & 3.58 \\
3.28 & 3.87 \\
3.53 & 4.19 \\
\hline
\end{tabular}

*Mean of four replicate experiments with relative standard deviation $<4 \%, \mathrm{n}=4$

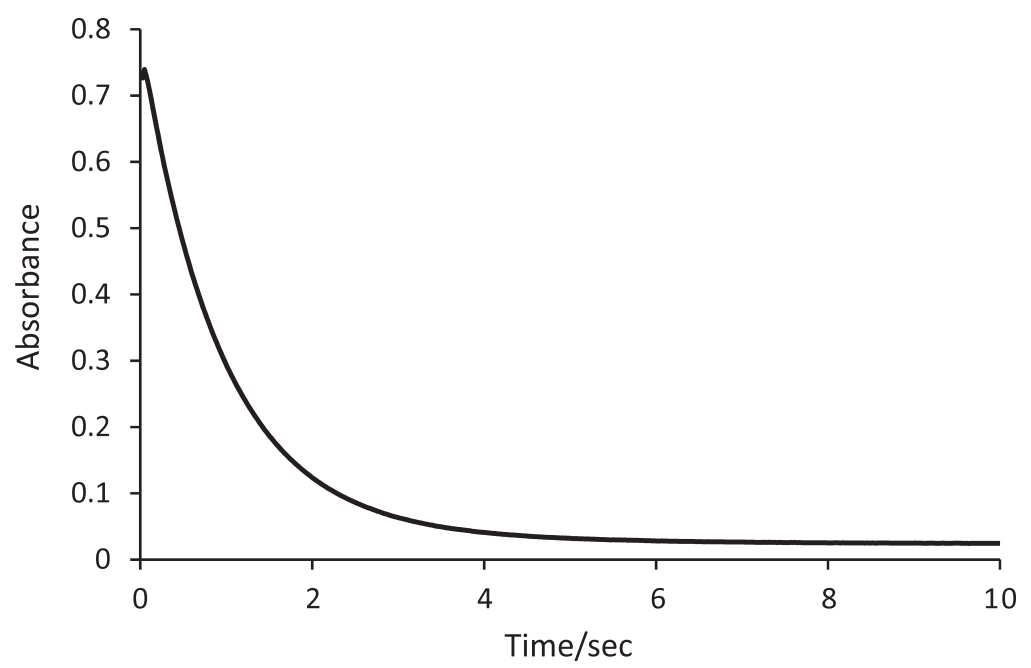

Figure 1 Absorbance versus time plot. Reaction conditions: $\left[\mathrm{BB}^{-}\right]_{0}=2.0 \times 10^{-5} \mathrm{M}$ and $\left[\mathrm{ClO}_{2}\right]_{0}=1.5 \times 10^{-2} \mathrm{M}$ at $\mathrm{pH}=9.0$. 


\subsection{Role of $\mathrm{pH}$ and Hydroxide Ion}

While chlorine or hypochlorite react with substrate by additon or substitution reactions, $\mathrm{ClO}_{2}$ abstracts free radical during the attack. ${ }^{44}$ Furthermore, the reactivity of chlorine and hypochlorous acid increase with decreasing $\mathrm{pH}$. Chlorine dioxide exhibits no reactivity at low $\mathrm{pH}$, but it becomes reactive at neutral $\mathrm{pH}$ and above. ${ }^{45}$ To evaluate the effect of hydroxide ion, similar to the earlier studies, ${ }^{35}$ a set of experiments were carried out to establish the $\mathrm{k}^{\prime}$ rate coefficients (pseudo first-order), at varied $\mathrm{pH}(7,8$ and 9$)$ and at different initial concentrations of $\mathrm{ClO}_{2}$. Table 2 summarizes the $\mathrm{k}^{\prime}$ values as function of $\mathrm{ClO}_{2}$ concentration at different initial hydroxide conditions. Perusal of the results indicates that the increase in hydroxide concentration has a profound positive effect on the rate constants. The log-log plots of $\mathrm{k}^{\prime}$ and $\left[\mathrm{ClO}_{2}\right]_{0}$ gave slopes equivalent to $0.99,1.05$ and 1.02 at pH 7.0, 8.0 and 9.0, respectively. The observed reaction order with respect to $\mathrm{ClO}_{2}$ under different $\mathrm{pH}$ conditions was unity, suggesting that reaction mechanism is unaltered.

To establish the reaction mechanism and activity of hydroxide with fixed initial concentrations of dye and $\mathrm{ClO}_{2}$ the reaction was studied under diverse initial concentrations of hydroxide ion. Table 3 illustrates the obtained results. Similar to our earlier observations on oxidative degradation of Amaranth by chlorine dioxide ${ }^{35}$ the obtained results can be explained in terms of oxidation of Brilliant blue through two competitive reactions, i.e. first one by direct attack of chlorine dioxide on the cationic dye, which is slow reaction; and the second one involving chlorine dioxide, dye and hydroxyl ion, a faster one. At high $\mathrm{pH}$, i.e. with excess presence of $\mathrm{OH}^{-}$, the second reaction will remain predominant. At very low $\left[\mathrm{OH}^{-}\right]$conditions, the very slow reaction will prevail. The rate-limiting reactions may be expressed as follows:

$$
\mathrm{ClO}_{2}+\mathrm{BB}^{-} \rightarrow \mathrm{ClO}_{2}^{-}+\mathrm{BB} \text { (Very slow) }
$$

Table 2 Rate constants for the reaction of $\left[\mathrm{BB}^{-}\right]_{0}\left(2.0 \times 10^{-5} \mathrm{M}\right)$ as function of $\left[\mathrm{ClO}_{2}\right]_{0}$ at $\mathrm{pH} 7.0,8.0$ and 9.0.

\begin{tabular}{ccc}
\hline & $\begin{array}{c}\mathrm{pH} 7.0 \\
\mathrm{k}^{\prime} / \mathrm{s}^{-1 *}\end{array}$ & $\mathrm{k} / \mathrm{M}^{-1} \mathrm{~s}^{-1}$ \\
\hline 2.52 & 0.76 & 30.15 \\
2.77 & 0.84 & 30.32 \\
3.03 & 0.92 & 30.36 \\
3.28 & 0.98 & 29.88 \\
3.53 & 1.07 & 30.31 \\
& Mean k with Std. dev.: & $30.2 \pm 0.2$ \\
\hline
\end{tabular}

\begin{tabular}{|c|c|c|}
\hline$\left[\mathrm{ClO}_{2}\right] / 10^{-2} \mathrm{M}$ & $\begin{array}{l}\mathrm{pH} 8.0 \\
\mathrm{k}^{\prime} / \mathrm{s}^{-1}\end{array}$ & $\mathrm{~K} / \mathrm{M}^{-1} \mathrm{~s}^{-1}$ \\
\hline 2.52 & 1.08 & 42.85 \\
\hline 2.77 & 1.15 & 41.51 \\
\hline 3.03 & 1.29 & 42.57 \\
\hline 3.28 & 1.38 & 42.07 \\
\hline \multirow[t]{2}{*}{3.53} & 1.54 & 43.62 \\
\hline & Mean k with Std. dev.: & $42.5 \pm 0.8$ \\
\hline \multicolumn{3}{|c|}{ pH 9.0} \\
\hline$\left[\mathrm{ClO}_{2}\right] / 10^{-2} \mathrm{M}$ & $\mathrm{k}^{\prime} / \mathrm{s}^{-1}$ & $\mathrm{k} / \mathrm{M}^{-1} \mathrm{~s}^{-1}$ \\
\hline 2.52 & 2.98 & 118.25 \\
\hline 2.78 & 3.24 & 116.54 \\
\hline 3.03 & 3.58 & 118.15 \\
\hline 3.28 & 3.87 & 117.98 \\
\hline \multirow[t]{2}{*}{3.53} & 4.19 & 118.69 \\
\hline & Mean k with Std. dev.: & $117.9 \pm 0.8$ \\
\hline
\end{tabular}

where $\mathrm{k}=\mathrm{k}^{\prime} /\left[\mathrm{ClO}_{2}\right]$,

* Mean of four replicate experiments with relative standard deviation $<4 \%$. $(\mathrm{n}=4)$
Table 3 Rate constants for the reaction of $\left[\mathrm{BB}^{-}\right]_{0}\left(2.0 \times 10^{-5} \mathrm{M}\right)$ with $\left[\mathrm{ClO}_{2}\right] \mathrm{t}$ $\left(1.5 \times 10^{-2} \mathrm{M}\right)$ as function of $\left[\mathrm{OH}^{-}\right]_{0}$.

\begin{tabular}{ccc}
\hline$\left[\mathrm{OH}^{-}\right]_{0} / \mathrm{M}$ & $\mathrm{k}^{\prime} / \mathrm{s}^{-1 *}$ & $\mathrm{k} / 10^{2} \mathrm{M}^{-1} \mathrm{~s}^{-1}$ \\
\hline $7.94 \times 10^{-8}$ & 1.03 & 0.29 \\
$1.26 \times 10^{-7}$ & 1.08 & 0.30 \\
$2.00 \times 10^{-7}$ & 1.16 & 0.33 \\
$3.16 \times 10^{-7}$ & 1.21 & 0.34 \\
$5.01 \times 10^{-7}$ & 1.33 & 0.38 \\
$7.94 \times 10^{-7}$ & 1.43 & 0.40 \\
$1.26 \times 10^{-6}$ & 1.61 & 0.46 \\
$2.00 \times 10^{-6}$ & 1.82 & 0.52 \\
$3.16 \times 10^{-6}$ & 2.08 & 0.59 \\
$5.01 \times 10^{-6}$ & 2.56 & 0.73 \\
$7.94 \times 10^{-6}$ & 3.64 & 1.04 \\
$1.26 \times 10^{-5}$ & 4.85 & 1.38 \\
\hline
\end{tabular}

${ }^{*}$ Mean of four replicate experiments with relative standard deviation $<4 \%$. $\mathrm{k}=$ $\mathrm{k}^{\prime} /\left[\mathrm{ClO}_{2}\right] .(\mathrm{n}=4)$

$\mathrm{BB}^{-}+\mathrm{ClO}_{2}+\mathrm{OH}^{-} \rightarrow\left\{\mathrm{BB}^{-} \mathrm{ClO}_{2} \mathrm{OH}^{-}\right\}$(Activated complex)

$\left\{\mathrm{BB}^{-} \mathrm{ClO}_{2} \mathrm{OH}^{-}\right\} \rightarrow \mathrm{ClO}_{2}^{-}+\{\mathrm{HOBB}\}^{-}$(Rate-determining step)

Summing up the contribution of the two competitive reactions, the probable rate of reaction may be stated as,

Rate $=\mathrm{k}_{1}\left[\mathrm{ClO}_{2}\right]\left[\mathrm{BB}^{-}\right]+\mathrm{K}_{\mathrm{OH}-}\left[\mathrm{ClO}_{2}\right]\left[\mathrm{OH}^{-}\right]\left[\mathrm{BB}^{-}\right]$

$=\left\{\mathrm{k}_{1}+\mathrm{k}_{\mathrm{OH}-}\left[\mathrm{OH}^{-}\right]\right\}\left[\mathrm{ClO}_{2}\right]\left[\mathrm{BB}^{-}\right]$

$=\mathrm{k}\left[\mathrm{ClO}_{2}\right]\left[\mathrm{BB}^{-}\right]=\mathrm{k}^{\prime}\left[\mathrm{BB}^{-}\right]$

In the above equations, $\mathrm{k}^{\prime}$ represents the pseudo first-order rate coefficient, when $\left[\mathrm{BB}^{-}\right]<\left[\mathrm{ClO}_{2}\right] \cdot \mathrm{k}=\mathrm{k}^{\prime} /\left[\mathrm{ClO}_{2}\right]$ is the secondorder rate constant at fixed $\mathrm{pH}$, where $\mathrm{k}=\left\{\mathrm{k}_{1}+\mathrm{k}_{\mathrm{OH}-}\left[\mathrm{OH}^{-}\right]\right\}$and $\mathrm{k}_{1}$ is the second-order rate coefficient for the uncatalyzed path between Brilliant blue and oxidant. $\mathrm{k}_{\mathrm{OH}-}$ represents catalytic constant for the hydroxide ion catalyzed path. Table 3 summarizes the calculated values for the second-order rate and Fig. 2 illustrates the graph of $\mathrm{k}$ versus $\left[\mathrm{OH}^{-}\right]$. An observation of Fig. 2 shows that the value of $y$-intercept $\left(\mathrm{k}_{1}\right)$ is trivial, signifying the reaction will be very slow with no presence of hydroxide ion. It is anticipated from the known inert behaviour of chlorine dioxide at low $\mathrm{pH}^{46}$ For the $\mathrm{OH}^{-}$catalyzed path $(\mathrm{pH}$ between 7.0 and $9.0), \mathrm{k}_{\mathrm{OH}-}$ the catalytic constant was large and equal to $9.0 \times$ $10^{6} \mathrm{M}^{-2} \mathrm{~s}^{-1}$ (Fig. 2) confirming that hydroxide catalyzed reaction is very fast.

Employing different molar ratios of dye and oxidant, the stoichiometry experiments. The residual concentrations of the substrate and chlorine dioxide reacted were determined based on their redisual and initial concentrations. The stoichiometric ratio between $\mathrm{BB}^{-}$and $\mathrm{ClO}_{2}$ was found to be roughly $1: 2( \pm 10 \%)$. The overall stoichiometry of the reaction is represented as follows:

$\mathrm{BB}^{-}+2 \mathrm{ClO}_{2}+3 \mathrm{OH}^{-} \rightarrow \mathrm{P}_{1}+\mathrm{P}_{2}^{2-}+2 \mathrm{ClO}_{2}^{-}+\mathrm{H}_{2} \mathrm{O}$

\subsection{Kinetic Salt Effect}

Profound effect of hydroxide ion on the rate of the reaction clearly suggests the role of hydroxide ion as catalyst and its involvement in the slow step of the reaction. To validate its role, the kinetic salt effect on the reaction rate was investigated using fixed concentrations of oxidant, dye and hydroxide. The log k' against square root of ionic strength graph was straight line and gradient of $0.90\left(R^{2}=0.97\right)$. The observed positive salt effect indicates that two-single like charged species are involved in the rate-determining which are possibly $\mathrm{OH}^{-}$and $\mathrm{BB}^{-}$ions.

\subsection{Energy Parameters}

The magnitude and sign of the thermodynamic parameters of the activated complex afford an insight into the nature of the transition state. Hence the kinetics of the title reaction were 


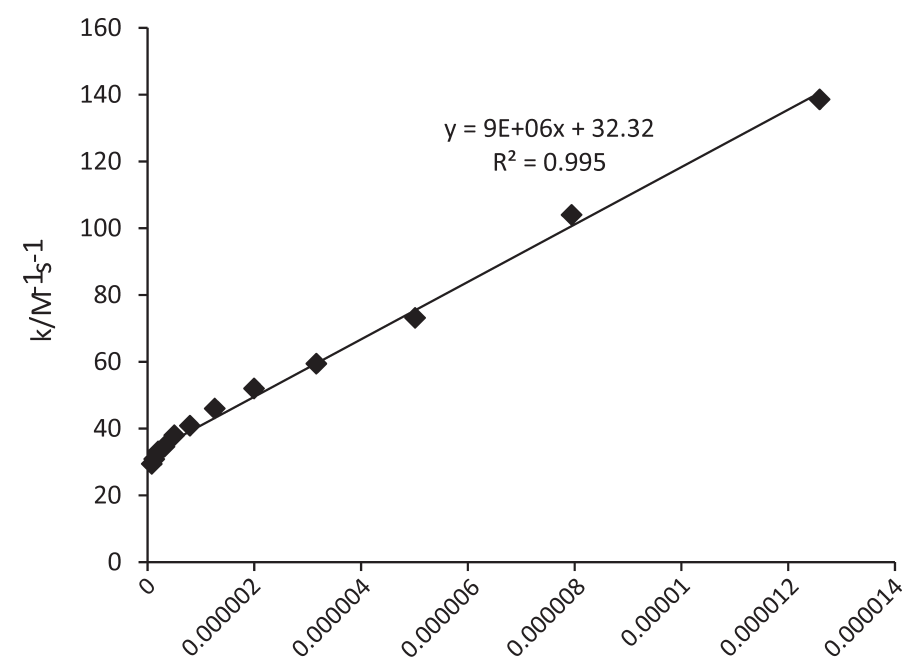

$\left[\mathrm{OH}^{-}\right]$

Figure 2 A plot of kagainst hydroxide ion concentration. Reaction conditions: $\left[\mathrm{BB}^{-}\right]_{0}=2.0 \times 10^{-5} \mathrm{M}$ with $\left[\mathrm{ClO}_{2}\right]_{0}=1.5 \times 10^{-3} \mathrm{M}$ and $\left[\mathrm{OH}^{-}\right]_{\mathrm{eq}}=7.94 \times$ $10^{-8} \mathrm{M}$ to $1.26 \times 10^{-5} \mathrm{M}$. ( $\mathrm{n}=4$ with less than $4 \%$ relative standard deviation).

investigated as function of temperature $\left(10^{\circ} \mathrm{C}\right.$ to $\left.30^{\circ} \mathrm{C}\right)$ and the values of activation energy, enthalpy and entropy were calculated. While the activation energy was estimated as $50.06 \mathrm{~kJ} \mathrm{~mol}^{-1}$ and and enthalpy of activation was $47.58 \mathrm{~kJ} \mathrm{~mol}^{-1}$ and the entropy of activation was negative and equal to $-676.36 \mathrm{~J} \mathrm{~K}^{-1}$ $\mathrm{mol}^{-1}$. The negative entropy value suggests a compact conformation of activated complex, which is the proposed feature of the activated complex in proposed mechanism.

\subsection{Product Characterization}

Column (silica gel stationary phase) chromatography was used to separate the reaction products from crude organic extract of the reaction mixture immediate after decolourization of the dye $(0.44 \mathrm{~g})$. Collecting $10 \mathrm{~mL}$ fractions in each step, mobile phase of hexane: dichloromethane (DCM) was used in stepwise gradient as follows: for the fractions 1-20 (100\% hexane), fractions $20-30$ (10\% DCM in hexane), fractions 30-40 (30\% DCM in hexane) and fractions 40-50 (50\% DCM in hexane) and so on. Compound one $(8 \mathrm{mg})$ with $50 \%$ dichloromethane as eluent and compound two $(5 \mathrm{mg})$ with $80 \%$ dichloromethane were obtained after fractionation and purification. The two products were positively identified as 4-(4-ethoxy-phenylamino)-benzoic acid (P1), and 3,3'-(biphenyl-4,4'-diylbis(ethylazanediyl))-bis (methylene) 3-dibenzenesulfonate (P2).

The proton NMR spectrum of the product $\left(\mathrm{P}_{1}\right)$ exhibited a triplet for methyl protons at $\delta 1.50$ and a quartet for the methylene protons at $\delta 3.62$ and two sets of doublets, at $\delta 8.07, \delta 7.92$ and $\delta 7.46$ (two overlapping resonances) for each of the ortho coupled protons on the two aromatic rings (Supplementary material, Fig. S1). The ${ }^{13} \mathrm{C}$ NMR indicated a carbonyl carbon resonance at $\delta 169.72$, an aromatic $\mathrm{C}$-O resonance at $\delta 149.47$ and aromatic carbons in the range of $\delta 116.18-140.09$. Carbon resonances are observed at $\delta 60.37\left(\mathrm{CH}_{2}\right)$ and $\delta 14.08\left(\mathrm{CH}_{3}\right)$ indicating the presence of the ethoxy group (Fig. S2). The GC-MS spectrum showed a molecular ion peak at $m / z 258\left(\mathrm{M}^{+}\right)$for the protonated product of P1. This corresponds to a molecular formula of $\mathrm{C}_{15} \mathrm{H}_{16} \mathrm{NO}_{3}$. The observed prominent peak $m / z=229$ was resultant of the ethyl group loss, and the peak at $\mathrm{m} / \mathrm{z} 110$ corresponds to the protonated $\mathrm{p}$-aminophenol that results from fragmentation of $P_{1}$ (cleavage of the carboxybenzyl and ethyl groups with concomitant hydrogen migrations) (Fig. S3).

The ${ }^{1} \mathrm{H}-\mathrm{NMR}$ of $\mathrm{P}_{2}$ displayed ethyl protons at $\delta 1.49$ followed by $\delta 4.17-4.19$ as triplet and quartets respectively representing the protons from the methyl and methylene groups. The benzyl methylene protons are observed at $\delta 5.29$ and aromatic protons are observed as in the range of $\delta 6.71-\delta 8.08$ (Fig. S4). The ${ }^{13} \mathrm{C}$ NMR spectrum showed two methyl carbon resonances $\delta 14.92$ and 14.98. At $\delta 60.37$ and $\delta 63.8$, the methylene carbon resonances were observed. Aromatic carbons are observed at $\delta$ 118.80-149.47 (Fig. S5). The mass spectrum of P2 exhibited molecular a molecular ion peak at $578\left(\mathrm{M}^{+}\right)$which was in agreement with the molecular mass of P2. The peak at $m / z 521$ is due to the fragmentation of two ethyl groups with simultaneous hydrogen migrations to the nitrogen atoms (Fig. S6).

\subsection{Mechanistic Scheme}

When Brilliant blue is reacted with the oxidant chlorine dioxide, the oxidizing agent removes an electron from the central olefinic bond of the molecule, resulting in a radical species which reacts with a hydroxyl radical to form the hydroxyl intermediate, $\mathrm{I}_{1}$. The the hydroxyl base abstracts a proton form the hydroxyl group producing the ketone $\mathrm{I}_{2}$ and $\mathrm{H}_{2} \mathrm{O}$. A hydroxide ion is substituted onto the ketone, which is driven by the positively charged nitrogen atom in a position para to the quinone ring, resulting in the benzoic acid, $P_{1}$ and the biphenyl product $P_{2}$. The probable mechanism for formation of the two oxidation products is illustrated in Scheme 1.

\subsubsection{Proposed Mechanism}

Based on the experimental results, the kinetic data, products identified and proposed mechanistic scheme, the overall reaction mechanism may be proposed as follows.

$$
\begin{aligned}
& \mathrm{BB}^{-}+\mathrm{ClO}_{2} \rightarrow \mathrm{BB}+\mathrm{ClO}_{2}^{-} \mathrm{R} 1 \\
& \mathrm{BB}+\mathrm{OH}^{-} \rightarrow \mathrm{I}_{1}^{-} \mathrm{R} 2 \\
& \mathrm{BB}^{-}+\mathrm{ClO}_{2}+\mathrm{OH}^{-} \rightarrow \mathrm{I}_{1}^{-}+\mathrm{ClO}_{2}^{-} \mathrm{R} 3 \\
& \mathrm{I}_{1}^{-}+\mathrm{ClO}_{2}^{-} \rightarrow \mathrm{I}_{2}+\mathrm{ClO}_{2}^{-} \mathrm{R} 4 \\
& \mathrm{I}_{2}+\mathrm{OH}^{-} \rightarrow \mathrm{I}_{3}^{-} \mathrm{R} 5 \\
& \mathrm{I}_{3}^{-}+\mathrm{OH}^{-} \rightarrow \mathrm{P}_{1}+\mathrm{P}_{2}^{2-} \mathrm{R} 6 \\
& \text { Overall equation is } \\
& \mathrm{BB}^{-}+2 \mathrm{ClO}_{2}+3 \mathrm{OH}^{-} \rightarrow \mathrm{P}_{1}+\mathrm{P}_{2}{ }^{2-}+2 \mathrm{ClO}_{2}^{-}+\mathrm{H}_{2} \mathrm{O}
\end{aligned}
$$

\subsection{Simulations}

Simulations were done to validate the proposed mechanisms and to prove that it is the more probable one. Simkine 3 software was used to compute the kinetic profiles of the reactants, intermediates and products. ${ }^{47,48}$ The estimated rate constant were 


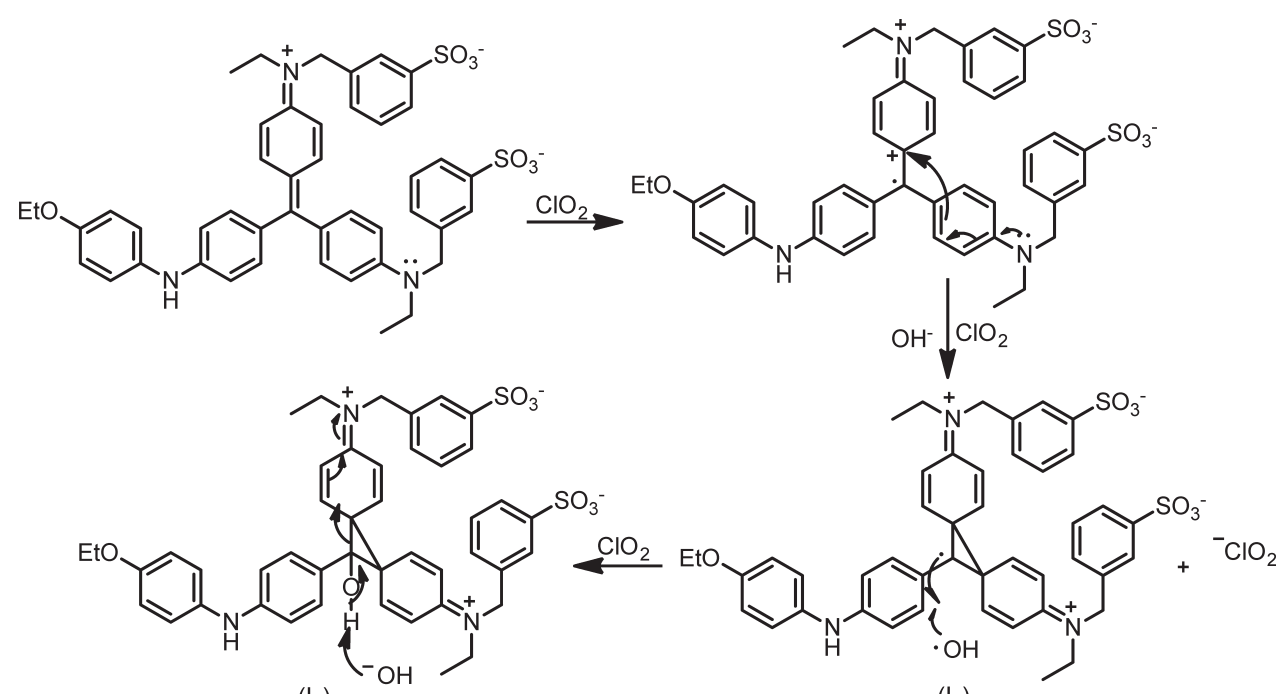

$\left(\mathrm{I}_{2}\right)$

$\left(I_{1}\right)$

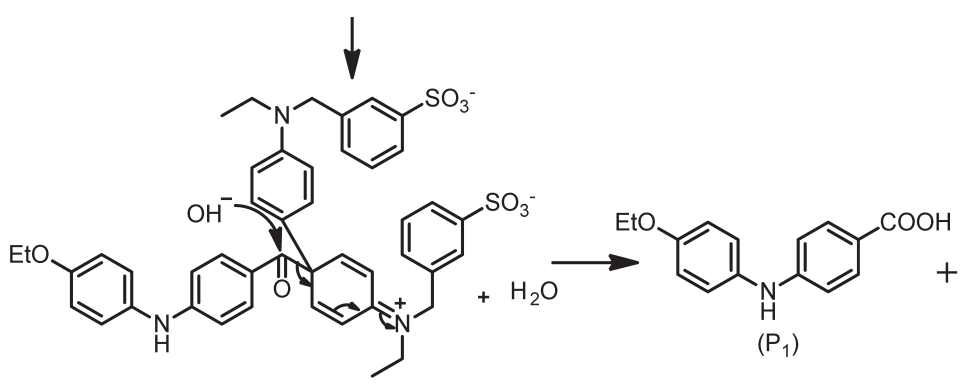

$\left(I_{3}\right)$<smiles>CCN(Cc1cccc(S(=O)(=O)[O-])c1)c1ccc(-c2cccc(N(CC)Cc3cccc(S(=O)(=O)[O-])c3)c2)cc1</smiles>

$\left(\mathrm{P}_{2}{ }^{2-}\right)$

Scheme 1

Mechanistic scheme for oxidation of Brilliant blue-R with chlorine dioxide.

optimized and adjusted until the simulated curves the product analysis gives details for the intermediate structures. The computed curves agreed well with the experimental kinetic profiles, confirming the suggested mechanism to be probable (Fig. 3). The rate constants used for $\mathrm{C} 1$ and $\mathrm{C} 3$ in simulations were experimental values and C2, C4, C5 and C6 were the estimated rate constants. Figure 4 illustrates experimental E1 and simulated S1 together with the profiles of intermediates and final products $P_{1}$ and $\mathrm{P}_{2}$. A fair agreement in between the experimental curves and the computed profiles, endorse the probability of the proposed mechanism.
Table 4 Rate equations and coefficients used for simulations.

\begin{tabular}{lll}
\hline & Reaction & Forward rate \\
\hline $\mathrm{C}^{*}$ & $\mathrm{BB}^{-}+\mathrm{ClO}_{2} \rightarrow \mathrm{BB}+\mathrm{ClO}_{2}^{-}$ & $3.23 \times 10^{2} \mathrm{M}^{-1} \mathrm{~s}^{-1}$ \\
$\mathrm{C} 2$ & $\mathrm{BB}+\mathrm{OH}^{-} \rightarrow \mathrm{I}_{1}^{-}$ & $7.00 \times 10^{5} \mathrm{M}^{-1} \mathrm{~s}^{-1}$ \\
$\mathrm{C} 3^{*}$ & $\mathrm{BB}^{-}+\mathrm{ClO}_{2}+\mathrm{OH}^{-} \rightarrow \mathrm{I}_{1}^{-}+\mathrm{ClO}_{2}^{-}$ & $9.00 \times 10^{6} \mathrm{M}^{-2} \mathrm{~s}^{-1}$ \\
$\mathrm{C} 4$ & $\mathrm{I}_{1}^{-}+\mathrm{ClO}_{2}^{-} \rightarrow \mathrm{I}_{2}+\mathrm{ClO}_{2}^{-}$ & $2.30 \times 10^{6} \mathrm{M}^{-1} \mathrm{~s}^{-1}$ \\
$\mathrm{C} 5$ & $\mathrm{I}_{2}+\mathrm{OH}^{-} \rightarrow \mathrm{I}_{3}^{-}+\mathrm{H}_{2} \mathrm{O}$ & $2.45 \times 10^{6} \mathrm{M}^{-1} \mathrm{~s}^{-1}$ \\
$\mathrm{C} 6$ & $\mathrm{I}_{3}^{-}+\mathrm{OH}^{-} \rightarrow \mathrm{P}_{1}+\mathrm{P}_{2}^{2-}$ & $2.61 \times 10^{6} \mathrm{M}^{-1} \mathrm{~s}^{-1}$ \\
\hline
\end{tabular}

* Experimental values.

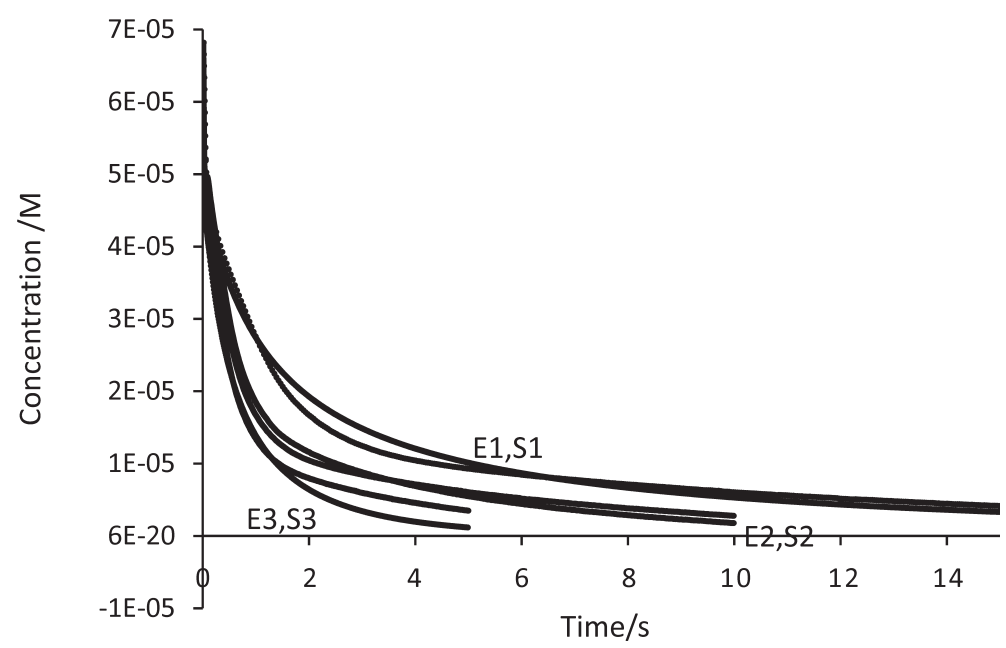

Figure 3 Experimental curves versus simulated curves. Reaction conditions: $\left[\mathrm{BB}^{-}\right]_{0}=2.0 \times 10^{-5} \mathrm{M}$ with varied $\mathrm{ClO}_{2}$ concentrations, $\left[\mathrm{ClO} \mathrm{O}_{2}\right]_{0} 10^{-2} \mathrm{M}, \mathrm{E} 1$ $=2.52$, $\mathrm{E} 2=3.03$ and $\mathrm{E} 3=3.53$ and $\mathrm{pH} 9.0$. 


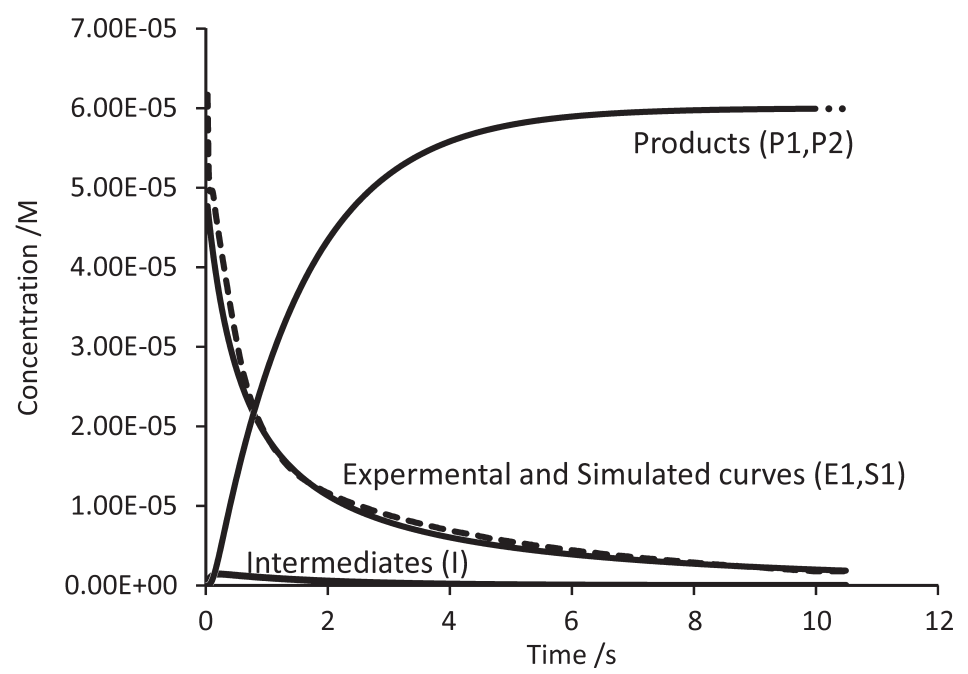

Figure 4 Typical experimental (E1).and simulated (S1) curves for $\mathrm{BB}^{-}$with kinetic profiles of intermediates and products. Conditions are same as in Fig. 3.

\section{Conclusions}

The main products of oxidation of Brilliant blue by chlorine dioxide immediately after its decolourization are 4-(4-ethoxyphenylamino)-benzoic acid (P1), and 3,3'-(biphenyl-4,4'diylbis(ethylazanediyl))bis(methylene) 3-dibenzenesulfonate (P2) and both are less toxic than the starting compound. While the catalysing characteristic of hydroxide ion is positively established, reaction orders with respect to Brilliant blue and chlorine dioxide were unity. The catalytic constant for the hydroxide ion catalyzed path was high and found to be $9.0 \times 106 \mathrm{M}^{-2} \mathrm{~s}^{-1}$.

\section{Acknowledgements}

The authors acknowledge the financial support received from the National Research Foundation, South Africa, in the form of bursary to SN.

\section{Supplementary Material}

Supplementary information is provided in the online supplement.

\section{${ }^{\S}$ ORCID iD}

S.B. Jonnalagadda: (D) orcid.org/0000-0001-6501-8875

\section{References}

1 N.C. Burton, A. Adhikari, Y. Iossifova, S.A. Grinshpun and T. Reponen, Effect of gaseous chlorine dioxide on indoor microbial contaminants, J. Air Waste Manage. Assoc., 2008, 58, 647-656.

2 C.M. Carliell, S.J. Barclay, C. Shaw, A.D. Wheatley and C.A. Buckley, The effect of salts used in textile dyeing on microbial decolourisation of a reactive azo dye, Environ. Tech., 1998, 19, 1133-1137.

3 T. Inoue, K. Kikuchi, K. Hirose, M. Iino and T. Nagano, Small molecule-based laser inactivation of inositol 1,4,5-trisphosphate receptor, Chem. Biol., 2001, 8, 9-15.

4 Y. Ji, X.T. Li and G.Q. Chen, Interactions between a poly(3-hydroxybutyrate-co-3-hydroxyvalerate-co-3-hydroxyhexanoate) terpolyester and human keratinocytes, Biomaterials, 2008, 29, 3807-3814.

5 T. Robinson, G. McMullan, R. Marchant and P. Nigam, Remediation of dyes in textile effluent: a critical review on current treatment technologies with a proposed alternative. Bioresour. Technol., 2001, 77, 247-255.

6 S. Rodriguez Couto, Dye removal by immobilised fungi,. Biotechnol. Adv., 2009, 27, 227-235.

7 H. Zollinger. Color Chemistry: Syntheses, Properties, Applications of Organic Dyes Pigments, Wiley-VCH, Weinheim, NY, 1991.

8 C.M. Carliell, S.J. Barclay, C. Shaw, A.D. Wheatley and C.A. Buckley, The effect of salts used in textile dyeing on microbial decolourisation of a reactive azo dye, Environ. Tech., 1998, 19, 1133-1137.
9 T. Inoue, K. Kikuchi, K. Hirose, M. Iino and T. Nagano, Small molecule-based laser inactivation of inositol 1,4,5-trisphosphate receptor. Chem. Biol., 2001, 8, 9-15.

10 J.I. Kroschwitz, Kirk-Othmer Encyclopedia of Chemical Technology. Wiley-Interscience, Hoboken, N.J., 2007.

11 S. Nihalani, A. Vijay, N. Tripathi and S. Bhardwaj, Photo catalytic water treatment by an eco friendly process- $\mathrm{BaO}_{3} \mathrm{TiO} . \mathrm{SrO}_{3} \mathrm{TiO}$ used in degradation of Malachite green and Crystal violet in aqueous suspension, IOSR-J. Appli. Chem., 2012, 2, 20-26.

12 S.L. Franklin, C. Jayadev, R. Poulsen, P. Hulley and A. Price, An ink surgical marker pen is damaging to tendon cells, Bone $\mathcal{E}$ Joint Res, $2012,1,36-40$. http://dx.doi.org/ 10.1302/2046-3758.13.2000032

13 R.D. Combes and R.B.H. Smith, A review of the genotoxicity of food, drug and cosmetic colours and other azo, triphenylmethane and xanthene dyes, Mutat. Res., 1982, 98, 101-248. http://dx.doi.org/ 10.1016/0165-1110(82)90015-X

14 http://www.sciencelab.com/xMSDS-Light_Green_SF_Yellowish9927208 (accessed on 3 May 2013).

15 W.H. Hansen, E.L. Long, K.J. Davis, A.A. Nelson and O.G Fitzhugh, Chronic toxicity of three food colourings: Guinea green B, Light green SF yellowish and Fast green FCF in rats, dogs and mice, Food $\mathcal{E}$ Cosmet. Toxicol., 1966, 4, 389-410.

16 A. Mittal, J. Mittal, A. Malviya, D. Kaur and V.K. Gupta, Decoloration treatment of a hazardous triarylmethane dye, Light green SF (yellowish) by waste material adsorbents, J. Collid. Interface. Sci, 2010, 342, 518-527. http://dx.doi.org/ 10.1016/j.jcis.2009.10.046

17 M.G. Allmark, H.C. Grice and W.A. Mannell, Chronic toxicity studies on food colours. II. observations on the toxicity of FD \& C green No. 2 (Light green SF yellowish), FD \& C orange No. 2 (orange SS) and FD \& C red No. 32 (oil Red XO) in rats, J. Pharm. Pharmacol, 1956, 8, $417-424$.

18 E. Forgacs, T. Cserháti and G. Oros, Removal of synthetic dyes from wastewaters: a review, Environ. Inter., 2004, 30, 953-971. http://dx.doi.org/ 10.1016/j.envint.2004.02.001

19 A. Bousher, X. Shen, R.G. Edyvean, Removal of coloured organic matter by adsorption onto low-cost waste materials, J. Water Res., 1997, 31, 2084-2092. http://dx.doi.org/ 10.1016/S0043-1354(97)00037-7

20 F. Gosetti, V. Gianotti, S. Angioi, S. Polati, E. Marengo and M.C. Gennaro, Oxidative degradation of food dye E133 brilliant blue FCF: liquid chromatography-electrospray mass spectrometry identification of the degradation pathway, J. Chromatogr., A, 2004, 1054,379-387. http://dx.doi.org/ 10.1016/j.chroma.2004.07.106

21 P. Bouras and P. Lianos, Photodegradation of dyes in aqueous solutions catalyzed by highly efficient nanocrystalline titania films. J. Appl. Electrochem., 2005, 35, 831-836. http://dx.doi.org/ 10.1007/s10800-005-1616-9

22 Z. Shen, W. Wang, J. Jia, J. Ye and X. Feng, A. Peng, Degradation of dye 
solution by an activated carbon fiber electrode electrolysis system, J. Hazar. Mater., 2001, 84, 107-116.

http://dx.doi.org/ 10.1016/S0304-3894(01)00201-1

23 R. Ahlawat, V.C. Srivastava, I.D. Mall and S. Sinha, Investigation of the electrocoagulation treatment of cotton blue dye solution using aluminum electrodes, Clean : Soil, Air, Water, 2008, 36, 863-869. http://dx.doi.org/ 10.1002/clen.200800019

24 G.S. Nyanhongo, J. Gomes, G.M. Gübitz, R. Zvauya, J. Read and W. Steiner, Decolorization of textile dyes by laccases from a newly isolated strain of Trametes modesta, Water Res., 2002, 36, 1449-1456. https://doi.org/10.1016/S0043-1354(01)00365-7

25 E. Abadulla, K.H. Robra, G.M. Gübitz, L.M. Silva and A.C. Paulo, Enzymatic decolorization of textile dyeing effluents. Tex. Res. J., 2000, 70, 409-414.

26 C.J. Ogugbue and T. Sawidis, Bioremediation and detoxification of synthetic wastewater containing triarylmethane dyes by Aeromonas hydrophila isolated from industrial effluent, Biotech. Res. Inter., 2011, 967925-967935. http://dx.doi.org/10.4061/2011/967925

27 K. Kumar, S. Saravana Devi, K. Krishnamurthi, S. Gampawar, N. Mishra, G.H. Pandya and T. Chakrabarti, Decolorisation, biodegradation and detoxification of benzidine based azo dye, Bioresour. Technol., 2006, 97, 407-413. http://dx.doi.org/ 10.1016/j.biortech.2005.03.031

28 C.P.L. Grady, Biodegradation of hazardous waste by conventional biological treatment, Hazard Waste Hazard. Mater., 1986, 3, 333-365. https://doi.org/10.1089/hwm.1986.3.333

29 T. Mushinga and S.B. Jonnalagadda, A kinetic approach for the mechanism of Malachite green-peroxydisulphate reaction in aqueous solution, Int. J. Chem. Kinet., 1992, 24, 41-49. http://dx.doi.org/ 10.1002/kin.550240106

30 S.B. Jonnalagadda, C. Chinake and R.H. Simoyi, Kinetics and mechanism of the reaction between Thymol blue and bromate in acidic medium, J. Chem. Soc. Faraday Trans., 1995, 91, 1635-1640. http://dx.doi.org/ 10.1039/FT9959101635

31 S.B. Jonnalagadda and M.A. Salem, Chemistry of a non-linear reaction between Aniline blue and acidic bromate, Phys. Chem. Chem. Phys., 1999, 1, 821-826.

32 P. Dachipally and S.B. Jonnalagadda, Kinetics of ozone-initiated oxidation of textile dye, Amaranth in aqueous systems. J. Environ. Sci. Health. Part A, 2011, 46, 887-897.

http://dx.doi.org/ 10.1080/10934529.2011.580201

33 S. Nadupalli, N. Koorbanally and S.B. Jonnalagadda, Kinetics and mechanism of the oxidation of Amaranth with hypochlorite, J. Phys. Chem. A, 2011, 115, 7948-7954.

http://dx.doi.org/ 10.1021/jp202812f

34 S. Nadupalli, N. Koorbanally and S.B. Jonnalagadda, Chlorine dioxide-facilitated oxidation of the azo dye Amaranth, J. Phys. Chem. A, 2011, 115, 11682-11688.

http://dx.doi.org/ 10.1021/jp206175s
35 I. Ofori, S. Maddila, J. Lin and S.B. Jonnalagadda, Chlorine dioxide oxidation of Escherichia coli in water - A study of the disinfection kinetics and mechanism, J. Env. Sci. Heal. A, 2017, 52, 1-9. http://dx.doi.org/10.1080/10934529.2017.1293993

36 R. Sylla and T. Gianni, Patterns of European Industrialization: the Nineteenth Century. Routledge, London, U.K., 1992.

37 S.B. Bukallah, M.A. Rauf and S.S. Ashraf, Photocatalytic decoloration of Coomassie brilliant blue with titanium oxide, Dyes \& Pigments, $2007,72,353-356$ http://dx.doi.org/ 10.1016/j.dyepig.2005.09.016

38 S. Nadupalli, N. Koorbanally and S.B. Jonnalagadda, Kinetics and mechanism of the oxidation of triaryl dye, Brilliant blue- $\mathrm{R}$ with OCl-/HOCl, S. Afr. J. Chem., 2015, 68 , 85-92.

39 R.W. Fullerton, WEFTEC 2007, 2007, 4801-4808.

40 G.C. White, The Handbook of Chlorination, Van Nostr Reinhold, New York, U.S.,1986.

41 S.B. Jonnalagadda, V.S.R. Pullabhotla, S. Maddila and E.C. Chetty, Ozone for drinking and wastewater treatment and for value added products, Int. J. Chem., 2011, 1, 119-129.

$42 \mathrm{~S}$. Sussman and W. Ward, Chlorine dioxide is an attractive (water) treatment alternative. J. Water Sewage Works, 1979, 120-121.

43 A.M. Dietrich, M. P. Orr, D.L. Gallagher and R.C. Hoehn, Tastes and odors associated with chlorine dioxide, J. Amer. Water Works Assoc., 1992, 84, 82-88.

44 B.W. Lykins and H.G. Griese, Using chlorine dioxide for trihalomethane control. J. Amer. Water Works Assoc., 1986, 71, 88-93.

45 R.C. Hoehn, A.M. Dietrich, W.S. Farmer, M.P. Orr, R.G. Lee, M. Aieta, D.W. Wood and G. Gordon, Household odors associated with the use of chlorine dioxide, J. Amer. Water Works Assoc., 1990, 82, $166-172$.

46 G.A. Gagnon, J.L. Rand, K.C.O. Leary, A.C. Rygel, C. Chauret and R.C. Andrews, Disinfectant efficacy of chlorite and chlorine dioxide in drinking water biofilms, Water Res., 2005, 39, 1809-1817. http://dx.doi.org/ 10.1016/j.watres.2005.02.004

47 B.R. Deshwal and H.K. Lee, Variation in $\mathrm{CIO}_{2} / \mathrm{Cl}_{2}$ ratio in the chloride-chlorate process under different conditions, J. Ind. Eng. Chem., $2004,10,667-673$.

48 S.B. Jonnalagadda, M. Shezi and B. Pare, Uncatalyzed and ruthenium(III)-catalyzed reaction of acidic chlorite with methylene violet, Int. J. Chem. Kinet., 2003, 35, 294-303. http://dx.doi.org/ 10.1002/kin.10128

49 S.B. Jonnalagadda, N. Paramasur and M.N. Shezi, A user-friendly programme 'Simkine' for simulation of kinetics involving complex reaction mechanisms, Comp. Biol. \& Chem., 2003, 27, 147-152. http://dx.doi.org/ 10.1016/S1476-9271(02)00084-1.10

50 M.N. Shezi and S.B. Jonnalagadda, Easy to use program 'Simkine 3 'for simulating kinetic profiles of intricate chemical systems and optimizing predictable rate coefficients therein. Bull. Chem. Soc. Ethio., 2012, 26, 267-277.

http://dx.doi.org/10.4314/bcse.v26i2 


\section{Supplementary material to:}

S. Nadupalli, V.D.B.C. Dasireddy, N.A. Koorbanally and S.B. Jonnalagadda, Kinetics of Oxidation of Triaryl Methane Dye, Brilliant Blue-R with Chlorine Dioxide, S. Afr. J. Chem., 2019, 72, 40-46. 


\title{
Chlorine dioxide Facilitated Oxidative Degradation of Brilliant blue-R in Aqueous Solutions- Kinetics and Mechanism
}

\author{
Srinivas Nadupalli, Venkata D. B. C. Dasireddy, Neil A. Koorbanally and Sreekantha B. \\ Jonnalagadda*
}

School of Chemistry \& Physics, University of KwaZulu-Natal, Westville campus, Chiltern Hills, Durban 4000, South Africa.

\begin{tabular}{|l|c|}
\hline \multicolumn{1}{|c|}{ Contents } & Pages \\
\hline $\mathbf{H}^{1}, \mathbf{C}^{13}$ Spectral characterization data of Product P1 (Figure S1 \& S2) & 2 \\
\hline GC-MS spectrum of major oxidation product P1 (Figure S3) & 3 \\
\hline $\mathbf{H}^{1}, \mathbf{C}^{13}$ Spectral characterization data of Product P2(Figure S4 \& S5) & 4 \\
\hline GC-MS spectrum of major oxidation product P2 (Figure S6) & 5 \\
\hline
\end{tabular}




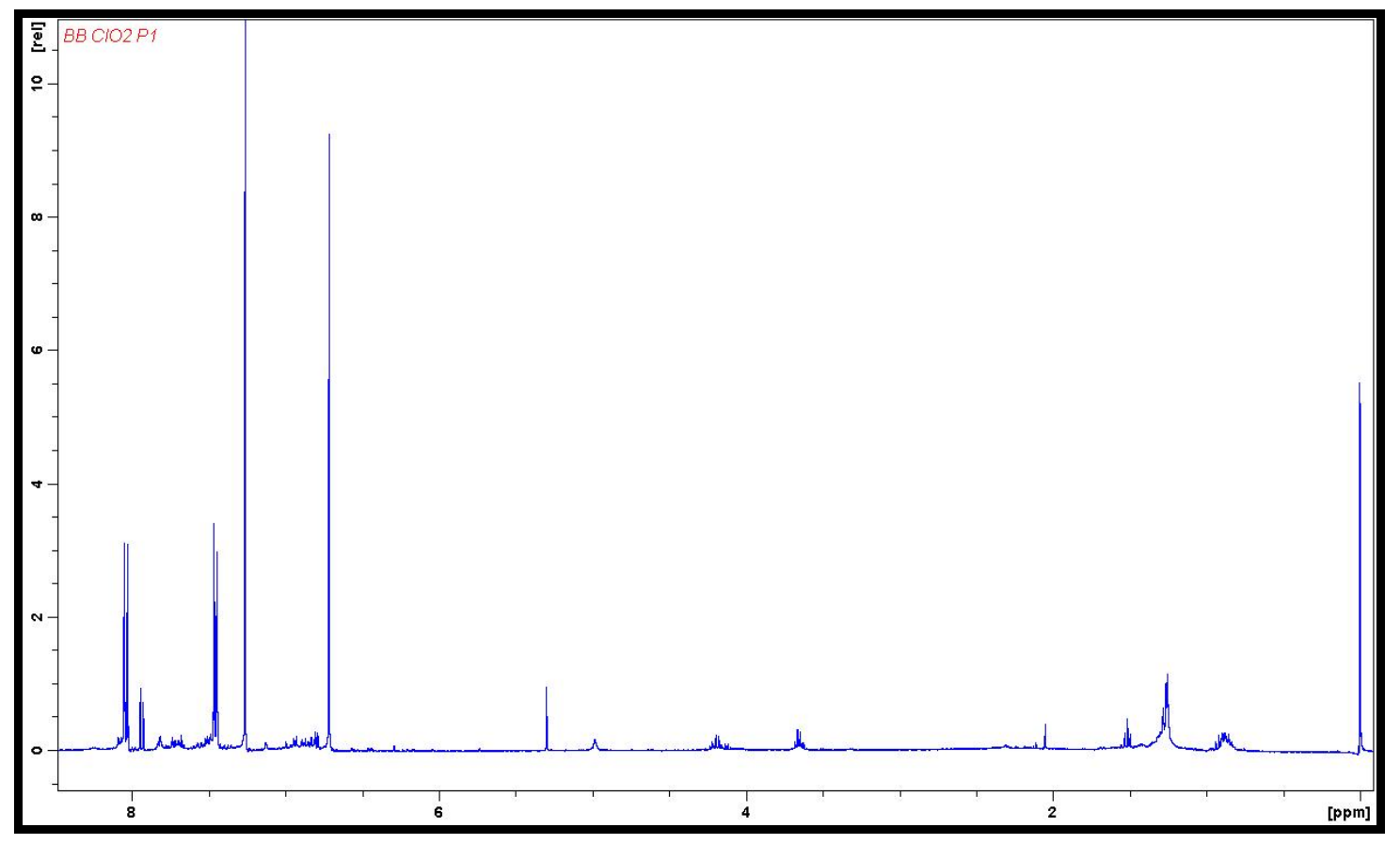

Fig. S1. ${ }^{1}$ H NMR spectrum for Product P1 4-(4-ethoxy-phenylamino)-benzoic acid.

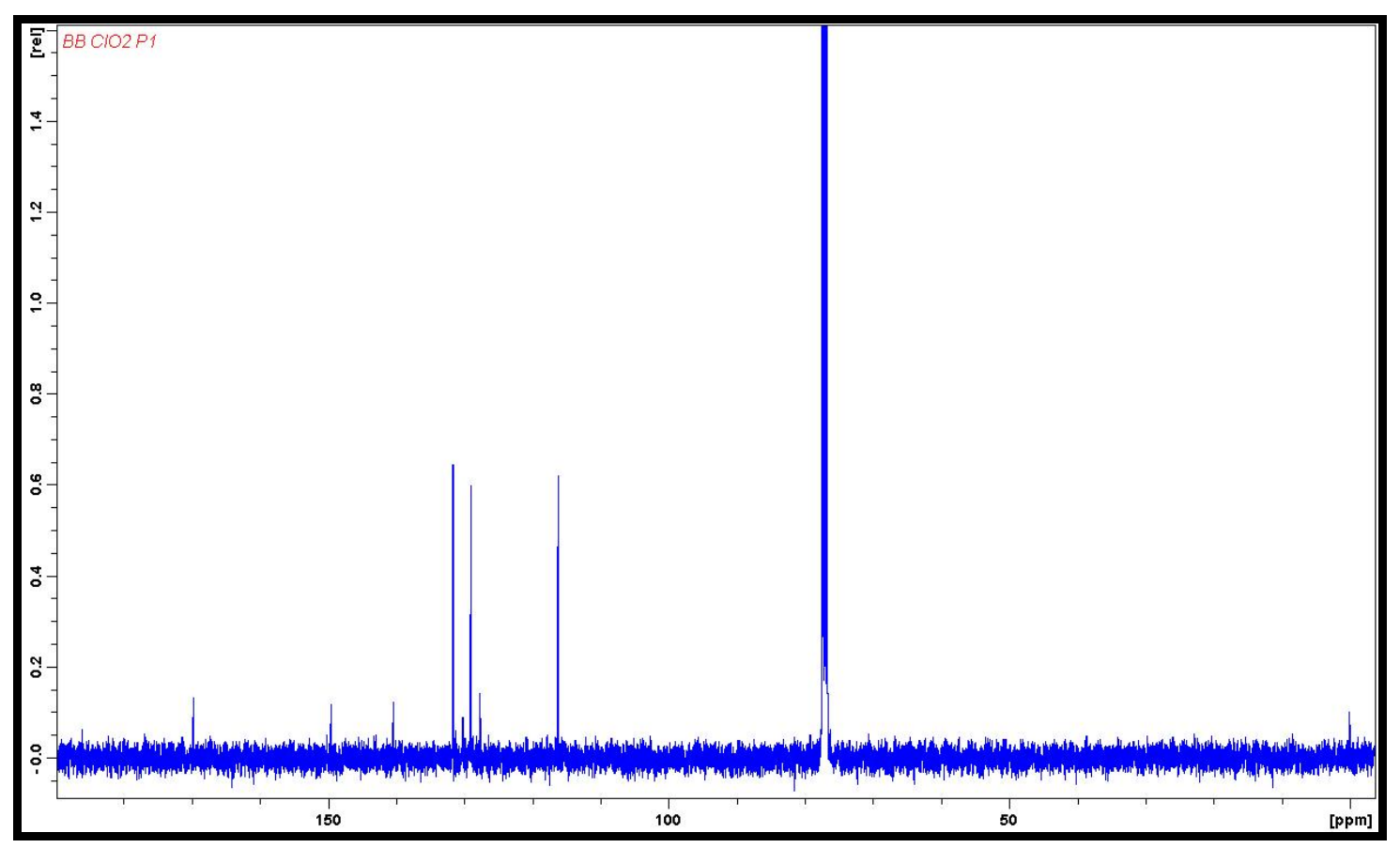

Fig. S2. ${ }^{13}$ C NMR spectrum for Product P1 4-(4-ethoxy-phenylamino)-benzoic acid. 


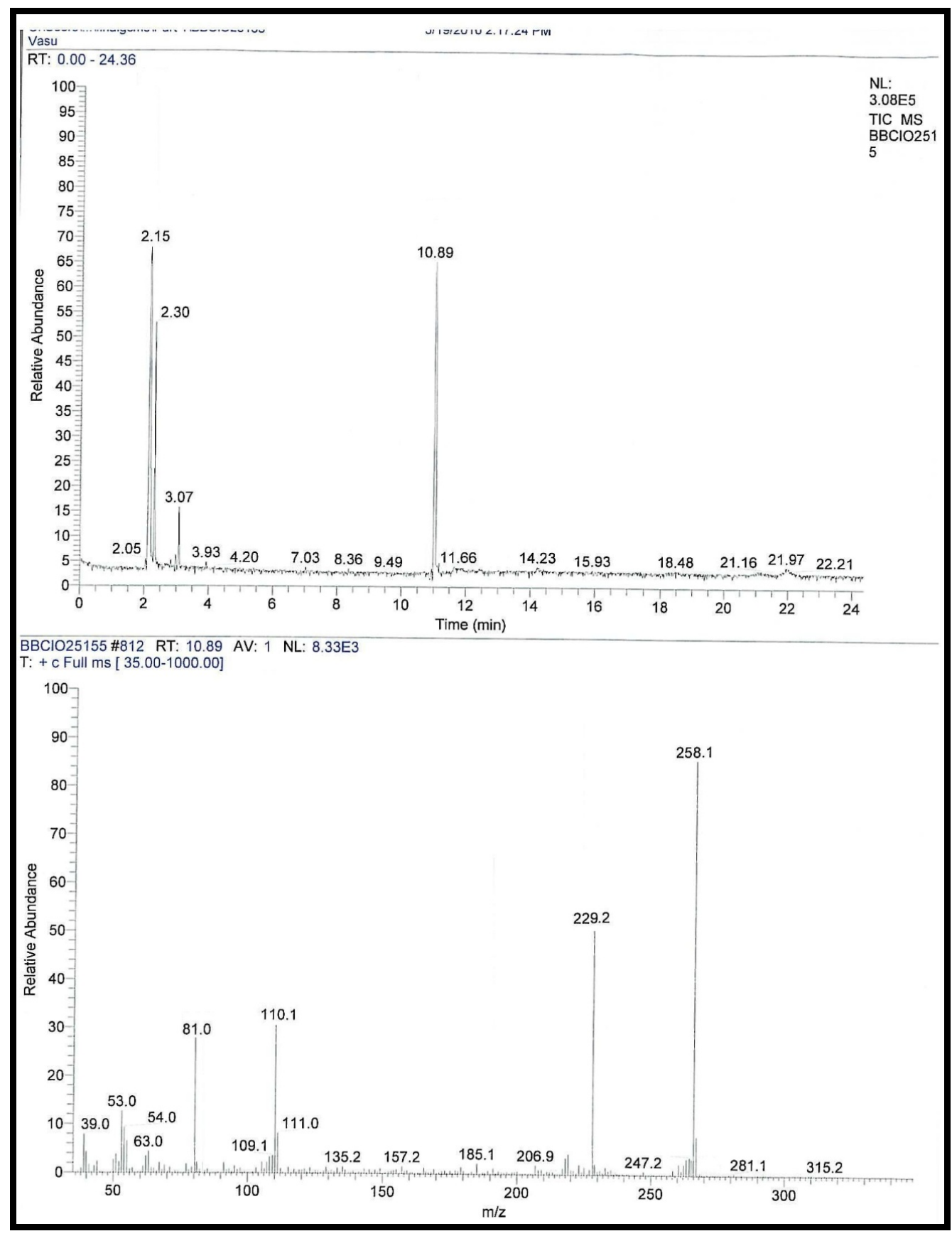

Fig. S3. GC-MS spectrum of brilliant blue-R major oxidation product P1 4-(4-ethoxyphenylamino)-benzoic acid). 


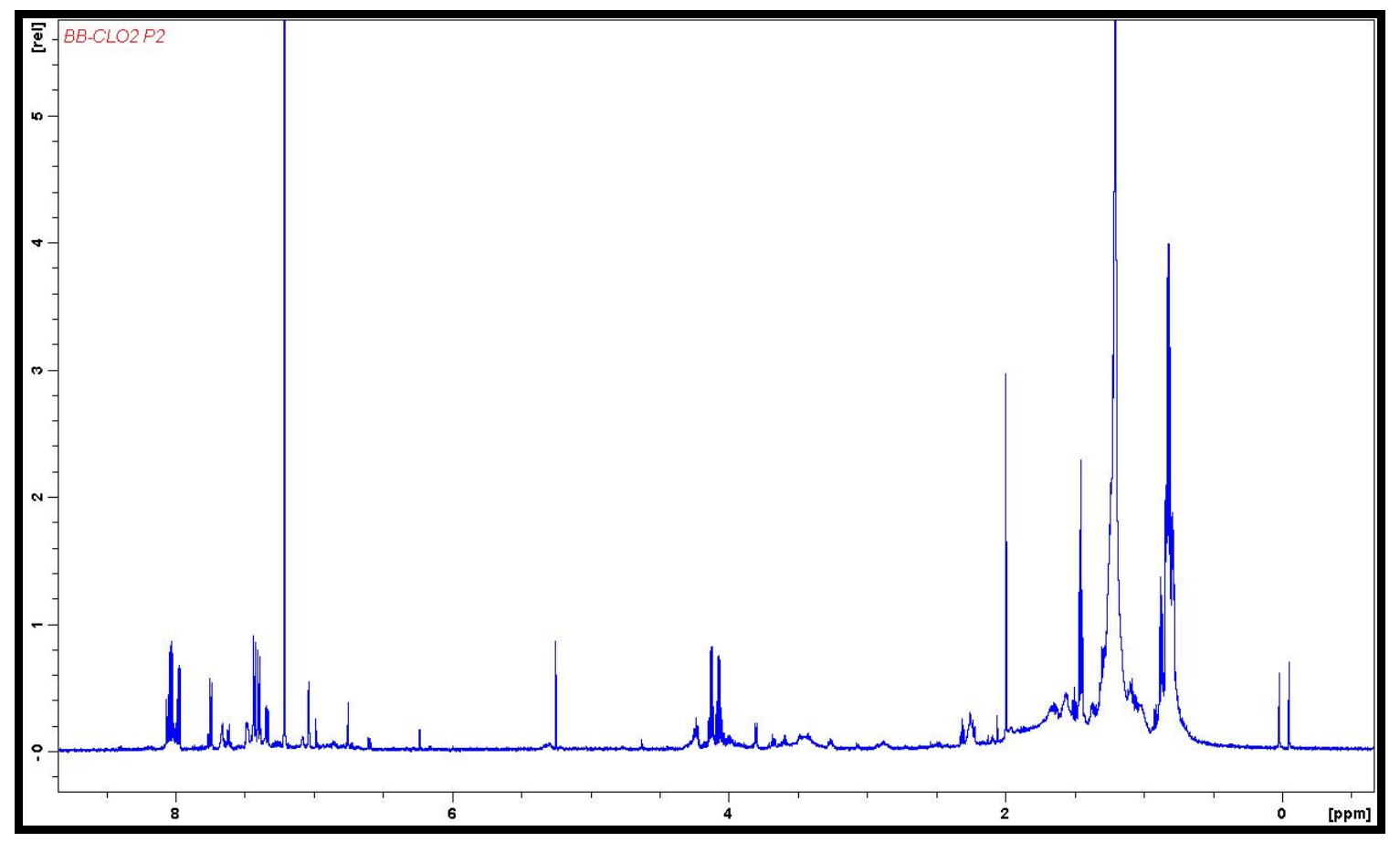

Fig. S4. ${ }^{1}$ H NMR Spectrum for Product P2 3,3'-(biphenyl-4,4' diylbis(ethylazanediyl))bis(methylene)dibenzenesulfonate.

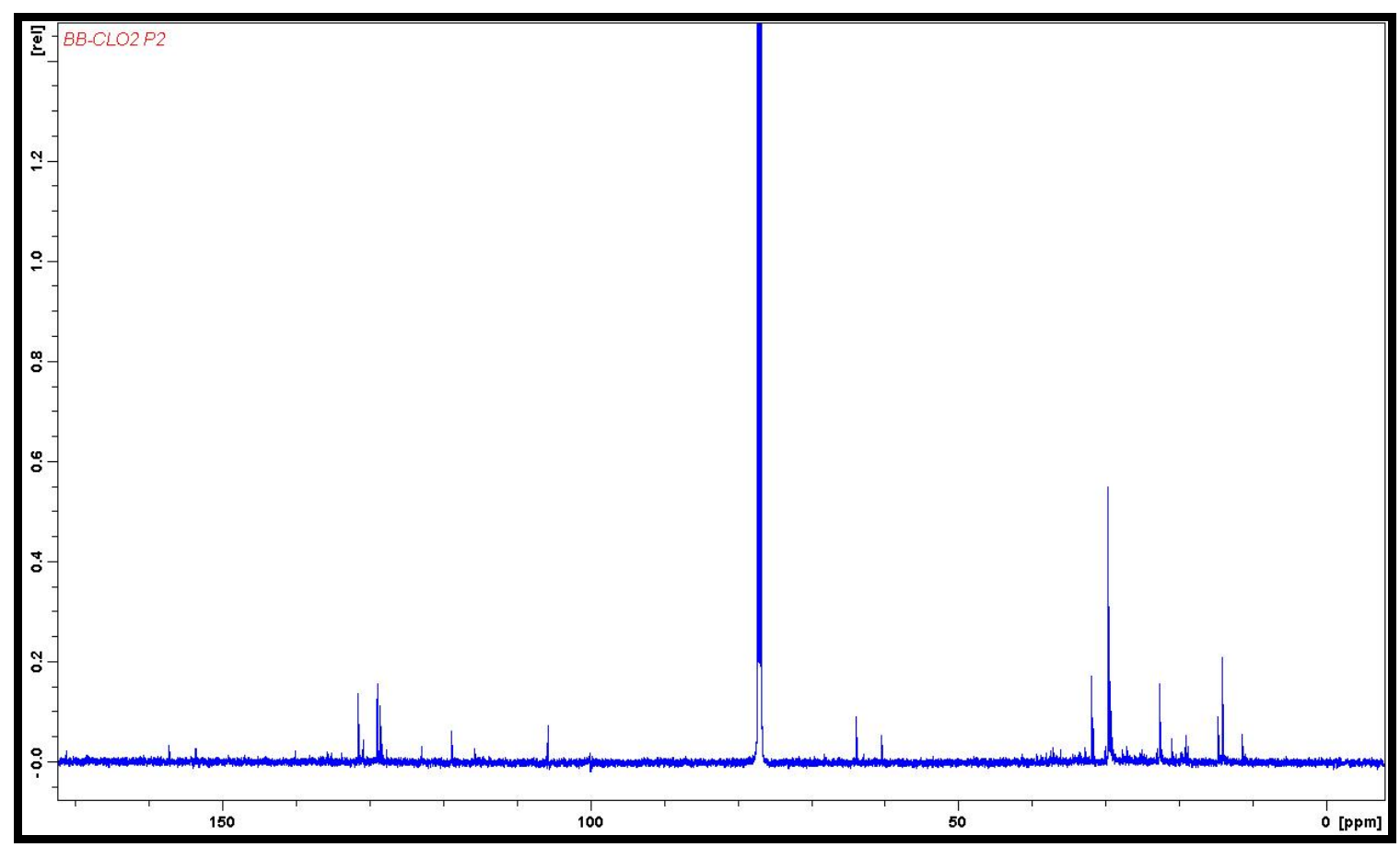

Fig. S5. ${ }^{13} \mathrm{C}$ NMR spectrum for Product P2 3,3'-(biphenyl-4,4'diylbis(ethylazanediyl))bis(methylene)dibenzenesulfonate. 


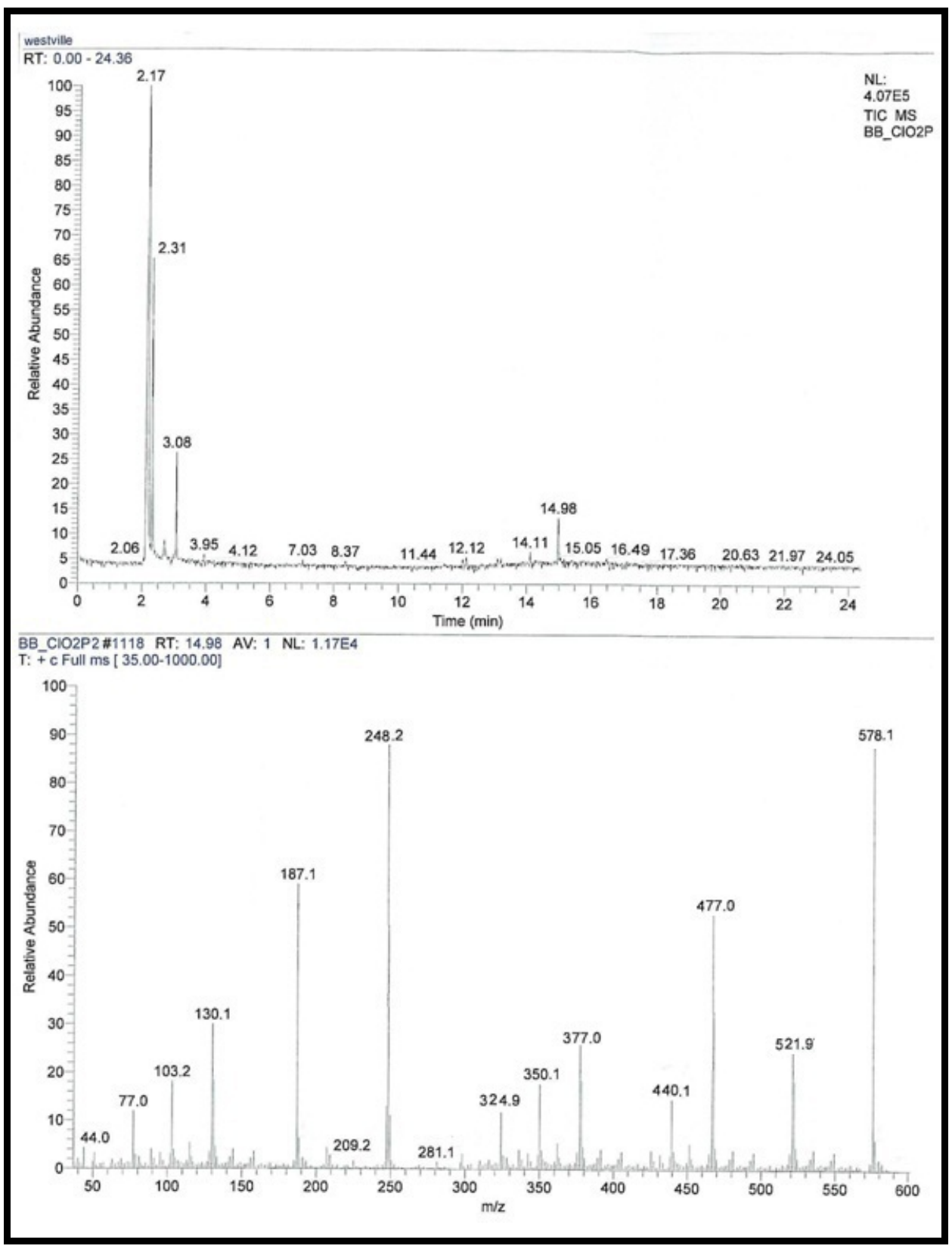

Fig. S6. GC-MS spectrum of brilliant blue-R major oxidation product P2 3,3'(biphenyl-4,4'-diylbis(ethylazanediyl))bis(methylene)dibenzenesulfonate. 